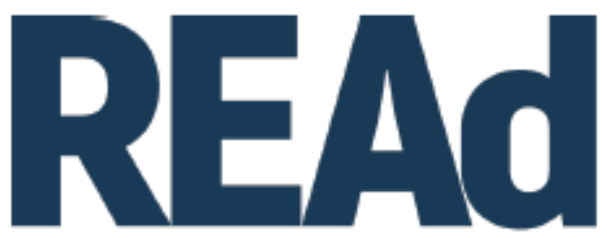

Revista Eletrônica de Administração

\title{
NOVO NEOLIBERALISMO: ARQUITETÔNICA ESTATAL NO CAPITALISMO DO SÉCULO XXI ${ }^{1}$
}

José Francisco Puello-Socarrás ${ }^{2}$

http://dx.doi.org/10.1590/1413-2311.309.111147

\section{RESUMO}

Este artigo apresenta as novidades chave e relativamente inéditas da nova fase do capitalismo neoliberal no século XXI. Sob a designação: Novo neoliberalismo, enfatiza-se os atributos cruciais deste processo econômico político. Ao redor do Estado Punitivo e Empreendedor de Trabalho (EPET) sintetiza sua Arquitetônica, ou seja, as reconfigurações do neoliberalismo tardio, as quais se encontram em relação com o desenvolvimento do Capitalismo contemporâneo e o tipo de Estado neoliberal em geral, os modos de estruturação dos aparatos estatais (atualmente: redes) em torno da nova gestão pós-burocrática e a modalidade típica de governo: a governança. A crise e a recomposição do neoliberalismo como um Projeto político da classe capitalista transnacional na virada dos séculos sugerem a transição para uma versão complexa e emergente (heterodoxa). Aqui as rupturas, no nível dos princípios e referências dos Programas de políticas públicas, reforçam a continuidade histórica do processo econômico político no novo milênio.

Palavras-chave: Novo neoliberalismo. Neoliberalismo. Regulação / Desregulação. Ortodoxia / Heterodoxia. Estado de Trabalho. Estado punitivo. Estado empreendedor.

\section{NUEVO NEOLIBERALISMO: ARQUITECTÓNICA ESTATAL EN EL CAPITALISMO DEL SIGLO XXI}

Este artículo caracteriza las novedades claves y relativamente inéditas de la nueva fase del capitalismo neoliberal en el siglo XXI. Bajo la designación: Nuevo neoliberalismo, enfatiza en los atributos cruciales de este proceso económico político. Alrededor del Estado Punitivo y Emprendedor de Trabajo (EPET) sintetiza su Arquitectónica, es decir, las reconfiguraciones del

\footnotetext{
${ }^{1}$ Recebido em 29/11/2020, aceito em 2/3/2021.

${ }^{2}$ Escuela Superior de Administración Pública e Universidad Nacional de Colombia; Bogotá - Colômbia; http://orcid.org/0000-0002-8658-9543; josepuel@esap.edu.co; https://www.jfpolitics.com/.
} 
neoliberalismo tardío, las cuales se encuentran en relación con el desenvolvimiento del Capitalismo contemporáneo y el tipo de Estado neoliberal en general, los modos de estructuración de los aparatos estatales (actualmente: redes) en torno a la nueva gestión post-burocrática y la modalidad típica de gobierno: la gobernanza. La crisis y recomposición del neoliberalismo como Proyecto político de la clase capitalista transnacional en el recambio de los siglos sugiere el tránsito hacia una versión compleja y emergente (heterodoxa). Aquí las rupturas, al nivel de los principios y referenciales de los Programas de políticas públicas, potencian la continuidad histórica del proceso económico político en el nuevo milenio.

Palabras clave: Nuevo neoliberalismo. Neoliberalismo. Regulación / Desregulación. Ortodoxia / Heterodoxia. Estado de Trabajo. Estado punitivo. Estado emprendedor.

\section{NEW NEOLIBERALISM: STATE ARCHITECTONICS IN THE CAPITALISM OF THE 21 ${ }^{\text {ST }}$ CENTURY}

This paper embodies key and relatively unfolded novelties at new phase of neoliberal capitalism in the 21st century. Under the designation: New neoliberalism, it emphasizes the crucial attributes of currently political economic process. Through Entrepreneurial, Prisonfare \& Workfare State is possible to synthesize its architecture, to say, reconfigurations of late neoliberalism in relation to the evolving actually existing capitalism and the type of neoliberal state (in general), the modes of structuring the state apparatus (so-called: networks) around post-bureaucratic management and his typical forms of contemporary government: governance. Crisis (and redressing) of neoliberalism as a transnational political class project in the change of centuries suggests a crucial transition to a complex and emerging (heterodox) version. Here, ruptures enhance, at the level of the principles and reference frames of public policy programs, the historical continuity of the political economic process in the new millennium.

Keywords: New neoliberalism. Neoliberalism. Regulation / Deregulation. Orthodox / Heterodox. Prisonfare State. Workfare State. Entrepreneurial State.

\section{NOVO NEOLIBERALISMO? PRECEDENTES}

\footnotetext{
Estamos em uma encruzilhada. Lugares do continente estão voltando atrás; lugares do continente estão se instalando. O que vai acontecer? Uma das opções é uma espécie de neo-neoliberalismo. Já seu próprio nome soa fossilizado, estagnado..., ou seja, uma reedição desbotada, sem brilho das políticas dos anos 80, 90 que estão ocorrendo em alguns países da América Latina. É uma probabilidade? É! Qual o meu ponto de vista? Não é uma probabilidade de irradiação, não é um horizonte sedutor, é um horizonte por defeito, é uma opção por defeito... Mas é diferente o neo-neoliberalismo de hoje, de 2017, ao dos anos 80'... (GARCÍA LINERA, 2017).
}

A citação acima é um pronunciamento feito pelo (ex)vice-presidente da Bolívia, Álvaro García Linera (2017), em Montevidéu (Uruguai) durante o Ciclo de conferências: Ser de esquerda 
no Século XXI, evento convocado pela Frente Amplia e pela Fundação Liber Seregni. Ali García Linera apontou a existência de um "novo neoliberalismo".

Simultaneamente Alberto Acosta - ex-presidente da Assembleia Constituinte e ex-ministro durante o primeiro ano do mandato do Rafael Correa no Equador - juntamente com John Cajas em um artigo intitulado: “Correa, um neo-neoliberal”, colocaram o seguinte:

O governo do Correa conclui transformado em uma mera ferramenta para que o capital possa satisfazer sua voracidade acumuladora explorando trabalhadores e Natureza. Nesse sentido, o governo do Correa compartilha muitos objetivos dos governos neoliberais dos anos 80 e 90. Mas enquanto o velho neoliberalismo deixava de lado e reduzia ao Estado para que os grandes capitalistas explorassem livremente, o novo neoliberalismo fortalece ao Estado e o reúne com o grande capital - local e transnacional - para explorar os trabalhadores e a Natureza. Assim, Correa - e seu governo - tem instaurado uma espécie de neoliberalismo transgênico com a Intervenção do Estado: uma fase superior do neoliberalismo à qual chamaremos de neo-neoliberalismo (ACOSTA; CAJAS, 2017).

Um pouco antes dessas declarações, a edição 101 da revista: New Left Review incluiu um artigo de autoria do W. Davies quem propunha um neoliberalismo 3.0 e o qual foi finalmente intitulado: "Novo Neoliberalismo":

Se hoje vivemos sob o neoliberalismo, ele é manifestamente diferente do neoliberalismo que chegou ao poder ao final da década de 1970 e começo da de 1980, e também diferente ao que predominou a partir da de 1990 , no prolongado auge que precedeu a $2008 .$. O que tem surgido, quero sugerir, não é simplesmente outro "pós", senão uma nova fase do neoliberalismo organizada em torno de uns valores e atitudes punitivas... O que tem mudado desde 2008 não são tanto as técnicas de poder - que têm se mantido perturbadoramente constantes - quanto o espírito ou o significado da sua aplicação prática. (DAVIES, 2016, p. 132-133, grifos do autor).

Em Anatomia do Novo Neoliberalismo, mais recentemente, Pierre Dardot e Christian Laval asseveraram:

O neoliberalismo não apenas sobrevive como sistema de poder, mas que é reforçado enquanto tal. Há que se compreender essa singular radicalização, o que implica discernir o caráter tanto plástico quanto plural do neoliberalismo. Mas é necessário ir ainda mais longe e perceber o sentido das transformações atuais do neoliberalismo, ou seja, $a$ especificidade do que aqui chamamos o novo neoliberalismo. [ênfases próprio] (DARDOT; LAVAL, 2019).

Além das diversas interpretações que trazemos à tona, inclusive considerando o eventual desconforto que provocaria para várias audiências o barroquismo desta expressão, o termo "novo 
neoliberalismo" vem sendo gradualmente utilizado em âmbitos políticos e acadêmicos, não apenas nos debates e análises políticas na América Latina e o Caribe. A designação também aparece como uma forma de aproximar respostas a várias questões que surgem em meio da crise mais espetacular do capitalismo histórico, uma crise civilizatória que tem se pretendido apresentar eufemisticamente - pela hegemonia global como a "Grande Recessão"3.

É teoricamente conveniente e politicamente útil falar sobre um "novo neoliberalismo"? Se entendermos o neoliberalismo em geral como o capitalismo hoje realmente existente, uma fase específica e um padrão de (re)produção do Capital, e mais pontualmente: um momento singular e socio-histórico particular da evolução do sistema capitalista em seu estágio tardio, este artigo propõe: sim, é sim uma necessidade iminente. Não só seria justo com a história contemporânea e os episódios recentes que a constituem. Igualmente, é um exercício de reflexão iniludível com o propósito de questioná-lo radicalmente, desde sua raiz, em um sentido ao mesmo tempo abstrato e prático.

\section{0 "NOVO" DO NEOLIBERALISMO NO SÉCULO XXI}

A designação Novo Neoliberalismo (PUELLO-SOCARRÁS, 2008) foi inaugurada com o propósito de registrar uma série de mudanças dentro da matriz neoliberal: orientações ideológicas (abstratas) e práxis (concretas) tal e como vinham se consolidando durante o novo milênio.

\footnotetext{
3 As referências mencionadas coincidem em vários aspectos. Elas também induzem seletivamente - pelo menos - a três imprecisões ou desvios: i) vincular cronologicamente a emergência do neoliberalismo com os anos 80 e 90; inclusive, "finais da década de 1970", como se insinua em Davies; deixando de lado que a inauguração do neoliberalismo está intimamente associada com o autoritarismo e as ditaduras civis-militares acontecidas na América Latina, desde a década de 1960 embora, especialmente, na década de 1970. Os exemplos paradigmáticos são o Chile com Pinochet e a Argentina com Videla; não Thatcher e Reagan, acontecimentos posteriores. Nesta anotação, Dardot e Laval, parecem ter ainda um preconceito analítico demasiado centrado na evolução do neoliberalismo na Europa e nos Estados Unidos, relevante mas incompleto (DARDOT; LAVAL, 2013; 2018); não analisam que o lugar da construção in vivo do neoliberalismo é a espacialidade periférica, nessa altura, em um processo de transição transnacional -gradual, mas progressivo- em direção ao capitalismo integrado; ii) minimizar o neoliberalismo como uma questão de "políticas públicas" (sejam econômicas ou sociais), mesmo a um assunto governamental (incluindo uma questão de racionalidade sócio-política ou gouvernementalité), sem insistir o suficiente na sua ontologia crucial: um projeto político transnacional de classe; iii) o novo neoliberalismo, está longe de ser "deslustrado" ou mesmo "desbotado", como propõe Garcia Linera. Muito pelo contrário. Não se deve subestimar que se trata de uma versão renovada e, em termos globais desde o colapso financeiro de curto prazo (2007-2008) e o consequente aprofundamento da crise capitalista de longo prazo (1970 - atual, com o choque viral de 2020), o neoliberalismo - antes de tudo - saiu fortalecido; iv) Acosta está errado ao propor uma espécie de "neoliberalismo intervencionista" quando o neoliberalismo em geral, antigo ou novo, é claramente anti-intervencionista. A ação do Estado interventor (liberal) é uma coisa, o Estado regulador (neo-liberal), é outra.
} 
A marca emergente do capitalismo neoliberal não tem significado rupturas no sentido das transformações para este projeto político transnacional globalizado. Pelo contrário: ela continua aprofundando e reforçando as principais tendências do capitalismo tardio. Porém, os desafios teóricos (no conhecimento) e, especialmente, políticos (para a ação) em relação às transformações sociais que enfrenta o novo milênio exigem que suas "novas" formas, manifestações e configurações sejam destacadas.

Sem que possam ser interpretados como estritamente inéditos, desde meados da década de 1990 diferentes cenários econômico-políticos a nível local, regional e global tem postulado "caminhos" diferentes que são impossíveis de ignorar, ainda dentro da mesma trajetória econômico-política que tem estruturado o neoliberalismo.

$\mathrm{Na}$ virada dos séculos se evidenciaram, por exemplo, "reformulações" no nível das políticas públicas econômicas e "sociais", assim como novas fórmulas governamentais. Estes fatos levaram à predição prematura de uma mudança de época. Não obstante, vistas em retrospectiva e na sua qualidade de sintomas dos processos (ou seja, como consequências e não como "causas"), as mudanças instrumentais têm resultado ser expressões estritamente conjunturais que devem ser contrastadas com a continuidade eminentemente sócio-política do tipo de reprodução capitalista em vigor hoje.

O Novo neoliberalismo como tendência permitiria caracterizar os trânsitos registrados nos desempenhos relativamente diferenciais dentro do aprofundamento do neoliberalismo e suas crises. Em qualquer caso, a ponderação ideológica e o balanço a partir das práxis sobre o "novo" no neoliberalismo não pretende desafixar seus efeitos históricos nem superestimar o presente.

O reajuste progressivo dos horizontes de visibilidade 4 permite que à medida que avança a crise capitalista estrutural, de longo prazo e global em que o neoliberalismo é a resposta ofensiva por parte do Capital desde a década de 1970 novas situações facilitam o reconhecimento das condições sociais emergentes relativamente inéditas. Em última instância, ter e tomar consciência sobre os aspetos da vida social no século XXI. Apesar de que os processos de alienação ideológica e a ocultação sistemática das contradições sociais gradualmente se exacerbam - como nunca antes na história, também simultaneamente, estilhaçam-se. A realidade contraditória do capitalismo se

4 Esta noção teórica e operacional do R. Zavaleta Mercado (1975, p. 71) é chave para estes assuntos: "Marx não escreveu $O$ Capital porque era Marx, porque se se tratasse apenas do gênio Aristóteles poderia tê-lo escrito, senão porque ele estava já em condições de explorar um horizonte de visibilidade da sociedade que não existia até então. Tornou-se visível o que antes era invisível ou perceptível parcialmente". 
atualiza desvelando a exploração, a dominação e as opressões em diferentes níveis sócio-políticos, econômicos e culturais.

Este artigo caracteriza então o Capitalismo do século XXI sob a designação: Novo neoliberalismo. Sintetiza (teoricamente) a complexidade e as múltiplas determinações (empíricas) que este fenômeno convocaria sob um argumento geral que expõe, em primeiro lugar, uma "revisão" do neoliberalismo. É necessário continuar exortando até que ponto esta palavra - e seu conceito - é lícita para a análise e também legítima e útil para decifrar os atributos básicos ("arquitetônicos") e as características essenciais do capitalismo neoliberal hoje. Em um segundo momento, o documento expõe três elementos analíticos estruturais que devem ser considerados dentro da nova fase neoliberal: i) o tipo de Estado: Punitivo, Empreendedor e de Trabalho, EPET; ii) os modos de Governo e Organizacional (governança e pós-nova gestão público-privada); e, iii) a modalidade de ação institucional (regulatória). Em conjunto, estas dimensões configuram a atual armação neoliberal. Tanto a renovação heterodoxa do neoliberalismo quanto o chamado: "Consenso da Regulação" (estatal dos mercados) são chaves insubstituíveis para dar conta das novas características do capitalismo no século XXI.

\section{REVISITANDO O NEOLIBERALISMO: BREVIÁRIO HISTÓRICO E TEÓRICO ATUALIZADO}

\subsection{LIBERALISMO: VELHO E NOVO. NOME, DESIGNAÇÃO E MOÇÃO CONCEITUAL}

Além das possibilidades e interpretações acerca do neoliberalismo, parece ser preciso seguir insistindo em uma definição mínima.

L. von Mises, por exemplo, em distintas oportunidades invocou a "clara distinção" surgida entre o velho liberalismo (Älteren liberalismus), fundado com a economia política clássica, por um lado, e o novo liberalismo (Neuen liberalismus), pelo outro. Em obras como Socialismo e Liberalismo (1927) embora fossem marcadas similitudes entre um e outro, em qualquer caso, se enfatizavam suas diferenças. Outros referentes intelectuais dessa época como Alexander Rüstow, Milton Friedman o F.A. von Hayek também recriaram essa distinção, utilizando muito cedo o 
termo Novo liberalismo5 ${ }^{5}$ Hayek durante a primeira reunião da Sociedade Mont-Pèlerin em 1947 no discurso de abertura, afirmou na frente do auditório que “(...) se tivessem uma possibilidade de renascer os ideais que acredito que compartilhamos e para os que, apesar do que se tem abusado do termo, não há um melhor nome que o de neoliberais” (HAYEK, 1992) .

Hartwell, historiador e presidente da SMP entre 1992 e 1994, situa pontualmente o momento no qual essa designação teria se institucionalizado - por consenso! - como uma (auto)referência identitária: o Colóquio Walter Lippmann (realizado em 1938). Este cenário unifica ao redor de um novo projeto liberal, acolhendo "a recomendação original feita pelo Rüstow", agrega Hartwell (1995: 19) e o termo: neoliberalismo.

Tendo esclarecido o dito acima, desprendem-se algumas premissas fundamentais para o entendimento do fenômeno histórico e atual:

i) Descritivamente, a palavra "novo liberalismo" (e sua contração lícita: neoliberalismo) é uma designação que surge no interior de uma comunidade ideológica que, por consentimento, identifica-se com esse nome. Trata-se de uma comunidade ideológica (de pensamento em geral) e não "epistêmica" ligada exclusivamente a alguma disciplina das ciências sociais ou humanas em particular. Dois cenários $a b$ origine da nascente organização neoliberal: o Colóquio Walter Lippmann (REINHOUDT; AUDIER, 2018) e a Sociedade Mont-Pèlerin (HARTWELL, 1995) assim o ratificam. Ambos os conclaves foram frequentados gradualmente por acadêmicos (economistas, filósofos, cientistas políticos, sociólogos, etc.), bem como empresários e políticos por profissão, dentre outros perfis profissionais. Os dissensos entre correntes neoliberais são visíveis, acima de tudo, no nível da instrumentação. As tensões sobre como alcançar uma Sociedade de Mercado (não unicamente uma “economia de mercado"), desvanecem-se à hora das controvérsias estrita e eminentemente políticas, ou seja, o consenso em geral e o acordo fundamental - em palavras do próprio Hayek;

ii) Teórica e historicamente é uma noção conceitual que, desde suas expressões socioideológicas, propõe uma distinção básica e chave para decifrá-la: a diferença entre o Velho liberalismo propenso ao imaginário do laissez-faire, laissez-passer (“deixar

5 Em Capitalismo e Liberdade, M. Friedman utilizou a expressão: "novo liberalismo" para o contrapor ao "liberalismo do século XIX". Enquanto, A. Rüstow ia além, apresentando o Velho liberalismo como "Paleo-liberalismo" (Paläoliberalismus).

6 Entre outros participantes: M. Allais, A. Director, W. Eucken, M. Friedman, B. de Jouvenel, M. Polanyi, K. Popper, W. Röpke y G. Stigler. 
fazer, deixar passar" segundo a afamada frase do Gournay) e a ideia de autorregulação do mercado, por um lado; e, pelo outro, o Neoliberalismo, comprometido com a ideia da regulação da sociedade capitalista contemporânea. A ação estatal neoliberal se resume então em um tipo de planejamento descentralizado que pode assumir (e combinar simultaneamente, segundo a conjuntura histórica real $^{7}$ ) duas modalidades: a) Desregulatória, como propõem as correntes anglo-americanas ortodoxas do neoliberalismo, ou, b) Re-regulatórias como sustentam as vertentes heterodoxas austríacas, alemãs e italianas) (PUELLO-SOCARRÁS, 2013). Este tipo particular de ação estatal não deve se confundir com a intervenção estatal (à la Keynes) nem com a Planificação centralizada dos chamados Socialismos reais durante a segunda metade do século XX.

F. Hayek em Caminho da Servidão assinalou, precisamente: “(...) não há nada que tenha feito mais dano à causa liberal do que a néscia insistência de alguns liberais em uma certa aproximação a regras gerais, todas sob o princípio do laissez-faire" (HAYEK, 1944, p. 105). Enquanto, pela mesma época, Milton Friedman esclareceu perante um jornal norueguês em 1951: “(...) em vez da ideia antiga de que o laissez-faire é o meio para atingir este objetivo [Nota: limitar ao Estado de 'intervir'], o neoliberalismo propõe que a concorrência mostrará o caminho" (citado por MIROWSKI, 2013, p. 63).

Além de todas as consequências que se derivam deste tipo de análise, a escolha da palavra é válida. Permite caracterizar e sintetizar com relativa precisão diferentes manifestações desse fenômeno em distintos níveis (político econômico, ideológico, etc.). A seleção conceitual esclarece então que o neoliberalismo não é "leseferista" nem mantém qualquer relação com a ideia de autorregulação. O Neoliberalismo se baseia nas ideias da regulação/desregulação.

\footnotetext{
7 Dois exemplos relativos ao "controle de preços" podem ser ilustrativos. No teórico, Mises (1929, p. 140) em Uma crítica do intervencionismo considerou que, em termos propriamente neoliberais, a política de controle de preços (uma regulação!) não estava descartada como uma opção "impossível" (embora enfatizava que fosse "inadequada"). No concreto da história, as Bases da Política Econômica do Governo militar chileno - apelidado: "O Tijolo", plano econômico da ditadura cívico-militar-eclesiástica comandado por Pinochet e assessorado pelos chamados Chicago Boys e o "pai" do monetarismo Milton Friedman, ou seja, posições indiscutivelmente comprometidas com a desregulação através de políticas de "choque", postulavam simultaneamente: por um lado: "l. DAR COMPLETA LIBERDADE DE PREÇOS EM TODAS AQUELAS ATIVIDADES EM QUE EXISTA UM NÍVEL RAZOÁVEL DE CONCORRÊNCIA INTERNA E/OU EXTERNA"; logo em seguida, por outro lado: "2. ESTABELECER UM CONTROLE DE PREÇOS EFICIENTE EM TODAS AQUELAS ATIVIDADES EM QUE EXISTAM MONOPÓLIOS E OLIGOPÓLIOS NÃO SUJEITOS À CONCORRÊNCIA EXTERNA (...) Em forma de exemplo podemos nomear os casos mais óbvios: telefones, eletricidade, água, gás, locomoção (serviços em geral) e algumas atividades importantes como CAP, carvão, ENAP, SOQUIMICH, etc.” (CENTRO DE ESTÚDIOS PÚBLICOS, 1973, p. 88).
} 


\subsection{PROJETO POLÍTICO E COMUNIDADE IDEOLÓGICA: CLASSE E CAPITALISMO TRANSNACIONAL}

Levando em conta as trajetórias estratégicas e táticas real e idealmente existentes que têm sido construídas ao longo do último meio século, o neoliberalismo se expressa fundamentalmente como um projeto político transnacional da classe capitalista.

O neoliberalismo se manifesta primordialmente a partir de uma estratégia econômicopolítica hegemônica e neocolonial: o Desenvolvimento (em palavras do Mises, o "livre desenvolvimento do Capital") (PUELLO-SOCARRÁS, 2015; PLEHWE, 2009; 2015). No longo prazo, a reconstrução neoliberal do Estado governamental e organizativo ajustada às novas condições da acumulação capitalista tardia tem orientado um tipo de transformações estruturais que se resumem na subordinação progressiva da (re)produção das relações sociais ao Mercado. Deve-se notar que tanto as lógicas quanto as contradições mercantis do capitalismo atual se dinamizam paradigmaticamente dentro de uma espacialidade transnacional fruto da integração capitalista a nível global que se consolida justamente a partir da década de 1970. No curto prazo, o projeto político do neoliberalismo se instrumentaliza através de diferentes trajetos (ou trajetórias) conjunturais constituídos por programas de políticas públicas.

O Projeto político e os Programas de políticas neoliberais então resultam cruciais para uma (possível) caracterização econômica, política, histórica e atual do capitalismo contemporâneo (ver tabela 1).

No momento de decifrar a complexidade das novidades no neoliberalismo em vigor durante o século XXI, a dimensão ideológica é uma chave complementar que resulta iniludível ${ }^{8}$. A projeção eminentemente ideológica do neoliberalismo não se reduz nem ao retórico nem ao teórico9. Devese concebê-la como uma práxis política que se (retro)alimenta de todos estes elementos.

\footnotetext{
8 Há que assinalar que o neoliberalismo não se esgota em uma "ideologia" embora expresse sim uma visão do mundo, como ordem e organização capitalista que justifica e compreende suas práxis. Também não se limita a uma "teoria" no sentido das "disciplinas" (ciências sociais ou humanas). Em qualquer caso, o pensamento neoliberal tem se expressado sim - e encontra apoios - em aproximações teóricas como a economia (neoclássica), a sociologia e a ciência política convencionais, as teorias do direito, a administração pública e privada (empresarial), a filosofia, etc. Assim, o pensamento neoliberal não pode se reduzir a nenhuma delas.

9 Sublinhamos este aspecto, tendo em vista o fato que várias análises unilateralmente pretendem dar conta do "neoliberalismo realmente existente" (PECK; BRENNER; THEODORE, 2018, p. 3-15), subestimando a dimensão ideológica ou minimizando-a como "retórica" (pura?) (discursos falaciosos, falsos, enganosos) pragmática. Uma forma alternativa para articular crítica e complexamente o que diz e o que faz (efetivamente) o neoliberalismo, apontando a essa "lacuna", a oferece - entre outros - Mirowski (2013, p. 82-102) a partir dos "treze mandamentos" no
} 
Tabela 1. Continuidades e rupturas desde alguns "Consensos" neoliberais (1989-2001)

\begin{tabular}{|c|c|c|c|}
\hline Níveis & $\begin{array}{c}\text { Consenso de } \\
\text { Washington (1989) }\end{array}$ & $\begin{array}{c}\text { Consenso Pós-Washington } \\
\text { (1998) }\end{array}$ & $\begin{array}{c}\text { 'Dissenso' de Washington } \\
(2001)\end{array}$ \\
\hline $\begin{array}{l}\text { Princípios } \\
\text { gerais }\end{array}$ & $\begin{array}{c}\text { Modelo de Economia de } \\
\text { Mercado }\end{array}$ & $\begin{array}{c}\text { Modelo de Economia Social } \\
\text { de Mercado }\end{array}$ & $\begin{array}{c}\text { Modelo de Economia Social } \\
\text { de Mercado }\end{array}$ \\
\hline $\begin{array}{l}\text { Paradigma } \\
\text { estratégico de } \\
\text { Desenvolvimento }\end{array}$ & $\begin{array}{c}\text { DESENVOLVIMENTO } \\
\text { ECONÔMICO }\end{array}$ & $\begin{array}{c}\text { DESENVOLVIMENTO } \\
\text { ECONOMMICO E } \\
\text { INSTITUCIONAL }\end{array}$ & $\begin{array}{c}\text { DESENVOLVIMENTO } \\
\text { ECONOMICO COM } \\
\text { EQUIDADE SOCIAL }\end{array}$ \\
\hline Matriz & \multicolumn{3}{|c|}{ Acumulação de capital baseada e liderada pelo Mercado } \\
\hline Pressupostos & \multicolumn{3}{|c|}{ Estabilização macroeconômica } \\
\hline Orientação & \multicolumn{3}{|c|}{ Para 'fora' } \\
\hline $\begin{array}{l}\text { Princípios } \\
\text { específicos } \\
\text { Princípios para a } \\
\text { atuação política, } \\
\text { institucional e } \\
\text { para políticas } \\
\text { públicas }\end{array}$ & $\begin{array}{l}\text { Desregulação } \\
\text { Privatização } \\
\text { Liberalização } \\
\text { Descentralização } \\
\text { Internacionalização } \\
\text { Financeirização }\end{array}$ & $\begin{array}{l}\text { Regulação progressiva } \\
\text { Privatização competitiva } \\
\text { Liberalização controlada } \\
\text { Institucionalização } \\
\text { público-privada } \\
\text { Financeirização }\end{array}$ & $\begin{array}{l}\text { Re-Regulação progressiva } \\
\text { Privatização estratégica } \\
\text { Liberalização controlada } \\
\text { Descentralização } \text { público- } \\
\text { privada } \\
\text { Internacionalização } \\
\text { acordada } \\
\text { Financeirização }\end{array}$ \\
\hline $\begin{array}{l}\text { Programas de } \\
\text { atuação } \\
\text { Articulação } \\
\text { institucional das } \\
\text { políticas }\end{array}$ & $\begin{array}{l}\text { 1. Disciplina fiscal } \\
\text { 2. Re-priorização do gasto } \\
\text { público } \\
\text { 3. Reforma tributária } \\
\text { 4. Taxas positivas de } \\
\text { juros } \\
\text { 5. Taxas de câmbio } \\
\text { competitivas } \\
\text { 6. Liberalização } \\
\text { comercial } \\
\text { 7. Inversão Estrangeira } \\
\text { Direta } \\
\text { 8. Privatização } \\
\text { 9. Desregulação } \\
\text { 10. Direitos de } \\
\text { Propriedade }\end{array}$ & $\begin{array}{l}\text { 1. Controle à Inflação } \\
\text { 2. Controle ao Déficit } \\
\text { Orçamentário } \\
\text { 3. Promoção do } \\
\text { Crescimento a Longo Prazo } \\
\text { 4. Reforma Financeira } \\
\text { 5. Concorrência } \\
\text { 6. Complementariedade } \\
\text { Público-privada via } \\
\text { governo. } \\
\text { 7. Maior efetividade dos } \\
\text { Governos }\end{array}$ & $\begin{array}{l}\text { 1. Disciplina fiscal regulamentada } \\
\text { 2. Temperar expansões e } \\
\text { contrações do mercado } \\
\text { 3. Redes automáticas de proteção } \\
\text { social } \\
\text { 4. Escolas para os pobres } \\
\text { 5. Reforma tributária progressiva } \\
\text { 6. Oportunidades para a pequena } \\
\text { empresa } \\
\text { 7. Proteção dos direitos dos } \\
\text { trabalhadores } \\
\text { 8. Anti-discriminação. } \\
\text { 9. Sanear os mercados de terras } \\
\text { 10. Serviços públicos ao serviço } \\
\text { dos consumidores } \\
\text { "10+1". Reduzir o protecionismo } \\
\text { dos países ricos }\end{array}$ \\
\hline
\end{tabular}

Fonte: Autor com base no Puello-Socarrás (2016); Birdsall et alt. (2010); Williamson (1990; 1993); Stiglitz (1998).

Em primeiro lugar, graças ao maior protagonismo e à gradual visibilidade das posições neoliberais heterodoxas as quais, sob uma ênfase especial durante o novo milênio, contrastam com a rejeição - inclusive, o relativo abandono - das visões neoliberais ortodoxas que foram (intra)hegemônicas desde a inauguração in vivo do neoliberalismo. Esta mudança ideológica vem evidenciando um trânsito (interno) transcendental desde as versões anglo-americanas do

neoliberalismo, a cosmovisão neoliberal e, especialmente, a Teoria da "dupla verdade". Esta última é um debate convergente que destaca a clivagem de classe do projeto neoliberal e que apoia a tese sobre o Estado centauro formulada pelo L. Wacquant que enunciamos mais adiante. 
neoliberalismo, defensoras a limine da desregulação como forma privilegiada de ação institucional para a materialização da Sociedade de Mercado, em direção a versões do pensamento neoliberal inclinadas à regulação estatal (em função) dos mercados, ou seja, um conjunto amplo e seletivo de perspectivas austríacas, alemãs, italianas e suíças (ver Figura 1).

No balanço das práxis ideológicas, a atualização e a renovação do neoliberalismo no século XXI explicam-se pelo influxo cognitivo reativados pelas correntes da Heterodoxia neoliberal (PUELLO-SOCARRÁS, 2017). Trata-se de uma tendência na virada do século que adquire ainda mais relevância a partir do choque financeiro global de 2007/2008, um episódio sem paralelo no aprofundamento da crise do capitalismo histórico e resumido nesta forma pelo próprio neoliberalismo:

(...) a crise de Wall Street é para o fundamentalismo do mercado o que a queda do Muro de Berlim foi para o comunismo: ela diz ao mundo que este modo de organização econômica é insustentável. No final, todos dizem, esse modelo não funciona. Este momento é um sinal de que as declarações de liberalização do mercado financeiro eram falsas. (STIGLITZ,, 2008).

Uma forma de resumir as trajetórias ideológicas do neoliberalismo, agora determinantes dentro das "novas” orientações na recente construção deste projeto político, deve sublinhar:

a) A emergente primazia heterodoxa em torno do chamado Consenso regulatório, horizonte político e fórmula de ação institucional (PUELLO-SOCARRÁS, 2017) ${ }^{10}$.

b) As contribuições históricas do neoliberalismo austríaco e as emergentes do neoliberalismo italiano: Escola de Milão e os Bocconi boys (BLYTH, 2014; NICOLI; PALTRINIERI, 2019) dentro do ressurgimento do "empreendedor", suas teorias e suas práxis ${ }^{11}$. Trata-se

10 O neoliberalismo, certamente, só renuncia hic et nunc à "desregulação", nunca per secula seculorum; no entanto, a questão da "regulação" retoma cada vez mais força nos discursos e práxis. Como tem lembrado B. Stolowicz, a regulação e a desregulação são duas faces do mesmo projeto neoliberal e suas políticas. No laboratório in vivo et ab origine do neoliberalismo global: Chile em tempos do Pinochet, as fases de 'choque', identificadas com a versão ortodoxa do neoliberalismo - ao que a Klein (2007) chamou: a doutrina do shock -, foram concebidas simultaneamente políticas voltadas para a desregulação (por exemplo, inflação de preços) e a regulação sob uma Economia Social de Mercado (ESM). Assim ficou registrado em uma das muitas trocas epistolares entre o ditador austral e o pater putative do neoliberalismo, Milton Friedman (STOLOWICZ, 2016, p. 85).

11 Acudindo à distinção feita por Marx (1976, p. 114) entre a Economia política (clássica) do Smith, Ricardo, etc., e os economistas vulgares, no tema do empreendedorismo é necessário distinguir (de grau, embora não de substância) entre as teorias sobre o empreendimento (neoclássicas) do Schumpeter, Mises, etc., por um lado, e o empreendedorismo vulgar (chamado: "empreendedormania"), por outro. Além da duvidosa qualidade acadêmica deste tipo de produções, o conjunto da literatura vulgar sobre "empreendedorismo", desfruta hoje de grande divulgação e recepção entre vários públicos leitores (e audiovisuais), incluindo a simpatia que professam por eles, vários círculos acadêmicos considerados prestigiosos. Publicações que hoje são popularmente célebres por serem coroadas como best-sellers em 
não só de referentes (normativos e cognitivos) para a reorganização dos aparatos estatais e a reestruturação das políticas públicas. O empreendedor e o "espírito" do empreendorismo têm se posicionado como princípio antropológico guia de dinâmicas sociais, econômicas, culturais, políticas. A chamada "acumulação empreendedora" (PUELLO-SOCARRÁS, 2019).

c) As contribuições desde o neoliberalismo alemão histórico: Ordoliberalismo e Escola Social do Mercado sobre a indissociável relação entre o Estado e o Mercado, ultimamente espalhadas sob o eufemismo das "falhas do mercado". O Estado age regulando os mercados (nunca intervindo neles) com o objetivo de "corrigir" os problemas causados pelas contradições da concorrência mercantil, ou seja, a "desaglomeração social". Estas posturas poderiam sintetizar-se através de dois lemas neoliberais tipicamente heterodoxos: i) Não existe economia livre (ou "mercados livres") sem um Estado forte (Freie Wirtschaft, starker Staat intitulava-se a famosa conferência do Alexander Rüstow de 193212); e, ii) "Tanto Mercado quanto possível, tanto Estado quanto necessário" (So viel Markt wie möglich; so viel Staat wie nötig) (PUELLO-SOCARRÁS, 2008; 2015). Precisamente, as versões latinoamericanas e caribenhas do neoliberalismo heterodoxo, surgidas durante as primeiras décadas do século XXI, rotuladas como novo desenvolvimentistas, apoiam-se ideologicamente pela premissa: "Não há mercados fortes sem um Estado forte" (ver Bresser-Pereira, 2011). Para sintetizá-lo a partir de Brown (2019, p. 63): “(...) nenhum intelectual neoliberal procurou um estado fraco".

d) As fórmulas do neoliberalismo suíço desde a Escola de Genebra têm sido fundamentais para promover e materializar a ideia neoliberal, segundo a qual os mercados não são "naturais", senão produtos institucionais de uma construção política. Neste sentido, o neoliberalismo suíço tem enfatizado em tópicos relacionados com o redesenho institucional do Estado e o Direito (Statecraft \& law), e a Governança multinível, especialmente, no

\footnotetext{
âmbitos editoriais globais e locais (por exemplo: Pai rico, Pai pobre do R. Kiyosaki e S. Lechter, ou Pequeno porco capitalista de S. Macías), igualmente, programas e shows de televisão onde se insiste nisso. Esta é a diferença percebida no tratamento do empreendedorismo entre as perspectivas neoliberais: austríacas "clássicas" e a nova italiana. $12 \mathrm{O}$ discurso intitulado - justamente -: "Freire Wirtschaft - Starker Staat", na reunão: Verein für Socialpolitik, Rüstow (1932, p. 62-69) propunha: "Em qualquer caso, o novo liberalismo que pode ser defendível na atualidade, e o que eu defendo junto com meus amigos, exige um Estado forte, um Estado por cima da economia, por cima dos interessados, ali, onde está seu lugar. E deixem-me concluir com esta adesão a um Estado forte em interesse da política econômica liberal e à política econômica liberal em interesse de um Estado forte, já que uma condiciona à outra" [ênfase próprio].
} 
estágio inter-transnacional13. Daí que também se lhe tenha caracterizado como um "Ordoglobalismo" (ver Slobodian, 2018).

(Figura 1. Pilares ideológicos do pensamento neoliberal)

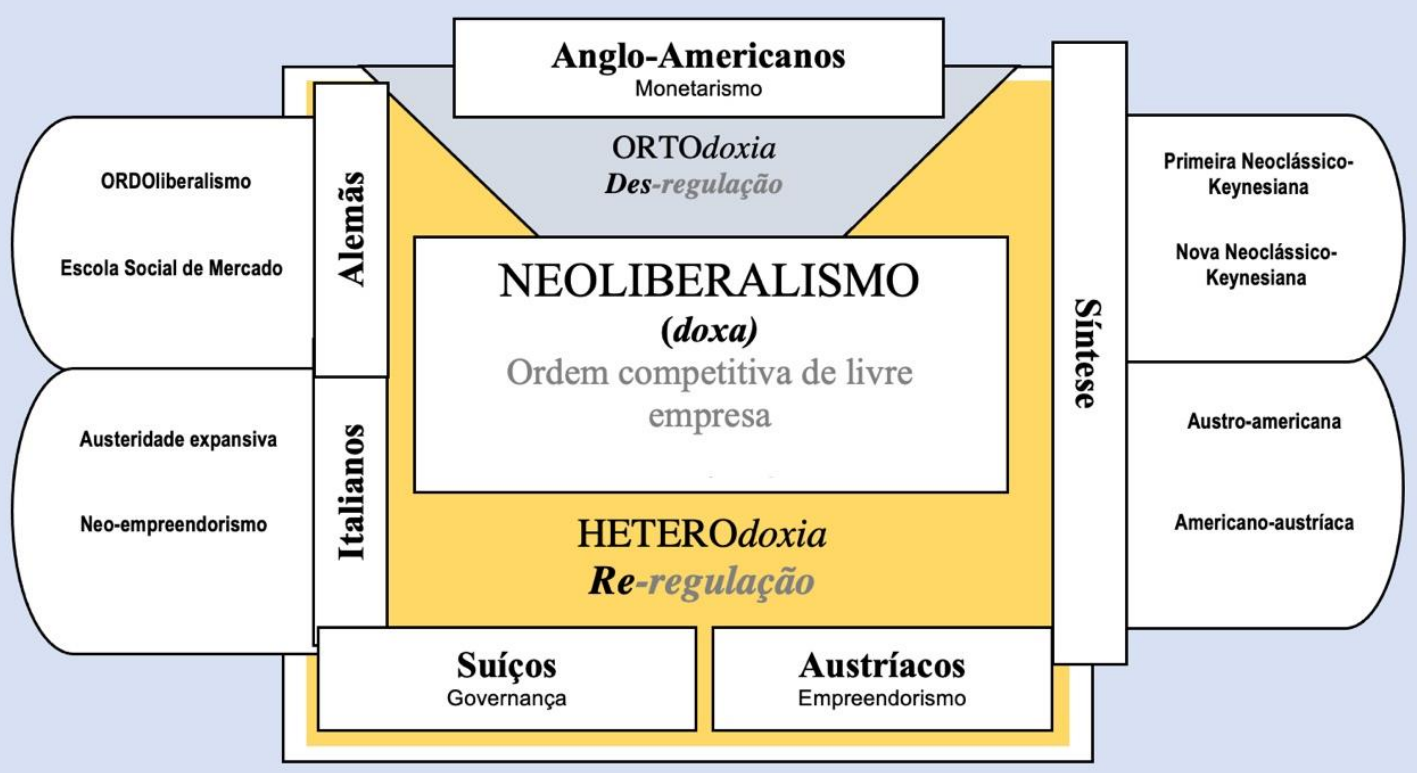

Fonte: Autor com base em Puello-Socarrás (2008), Plehwe (2009; 2015), Blyth (2014), \& Slobodian (2018).

\section{TRAJETÓRIAS NO NOVO NEOLIBERALISMO: ESTADO, GOVERNO, ORGANIZAÇÃO INSTITUCIONAL E AÇÃO PÚBLICA}

\section{$4.1 \mathrm{O}$ (NOVO) ESTADO NEOLIBERAL: TRABALHO, AUTORITARISMO E EMPREENDEDORISMO}

Mediante uma reconstrução histórica de longo prazo a progressiva constituição do Estado neoliberal poderia ser condensada em três (3) eixos paradigmáticos que, mesmo considerando-os como "momentos" característicos (temporais e conceituais), revelariam a marca das reconfigurações estruturais econômico políticas atuais: i) o Estado de Trabalho (Workfare state); ii) o Estado Punitivo (Prisonfare state); e iii) o Estado Empreendedor (Entrepreunerial state). No

13 Para Hayek, o choque de 1930 “(...) trouxe consigo a compreensão que a relação entre dois mundos - o de muitas nações e o de uma economia - teria que ser um projeto para redesenhar o Estado e, progressivamente após 1945, redesenhar o direito [Nota: e as leis]. A essência deste projeto foi a governança multinível ou o Federalismo neoliberal. Arrastados pela mistificação da economia mundial, o campo mais importante de influência do neoliberalismo da Escola de Genebra, não foi a economia per se senão o direito internacional e a governança internacional" (SLOBODIAN, 2018, p. 18). 
seu conjunto: o Estado Neoliberal Compreensivo (ENC), uma designação que também pode ser equivalente ao tipo de Estado Pós-burocrático Autoritário (EGA).

\subsection{ESTADO E TRABALHO (WORKFARE STATE)}

Embora Jessop (1993 e 2006) tem caraterizado o Estado Schumpeteriano / Ricardiano de Trabalho (EST), Workfare state, o tipo de regime estatal global (estrutural e estratégico) da época neoliberal, sua emergência e consolidação ainda é teórica e historicamente incompleta. O Estado de Trabalho além da sua ênfase Schumeperiana ou Ricardiana deve ser explicado necessariamente por uma dupla transição convergente: i) a crise do Estado Keynesiano de Bem-estar (EKB, Welfare state); e ii) o auge do Estado Burocrático Autoritário (EBA) (O’DONNELL, 1982; 2008, p. 63) também chamado Regime Tecnocrático Militar (RTM) (MARINI, 2013, p. 64). Desde o pós-guerra o EKB foi uma constituição social e uma construção estatal (quase)privativa do Capitalismo central euro-americano enquanto o EBA/RTM seria-o para o Capitalismo periférico, ou seja, a construção estatal típica na América Latina e o Caribe.

Geralmente as análises destacam unilateralmente apenas um dos caminhos da transição para o EST: a crise do EKB (além do Jessop, entre outros; ver SCHRAM, 2018, p. 308-322). Eles omitem que o processo de construção estatal, progressivamente globalizado durante a segunda metade do século XX, transforma-se desde a década de 1970 dentro do contexto da integração mundial do sistema capitalista. Daí em diante, a condição global econômico-política já não poderia se dissociar; melhor, exige que as análises incorporem as singularidades das trajetórias periféricas. Em especial: o auge da condição autoritária estatal, a qual torna-se em uma característica chave dentro do novo funcionamento do workfare. Em torno da estruturação do EST convergem então paralelamente tanto a retirada do EKB quanto a implantação gradual do EBA/RTM ${ }^{14}$.

14 É uma dinâmica que dentro da evolução complexa (não-linear) do sistema capitalista apontaram cedo Marx e Engels com "a segunda edição da servidão". Mais contemporaneamente, é o processo que ilustra C. Katz a propósito da periferização do centro capitalista ou J. Osorio quando adverte sobre a latino-americanização dos países europeus (considerados "desenvolvidos"). Além da denominação é chave notar: 1) “(...) no seio das relações capitalistas predominantes no sistema mundial, o subdesenvolvimento é uma forma madura de capitalismo, uma forma tão original e madura quanto o capitalismo desenvolvido"; e, nessa medida, 2) “(...) teoricamente é possível sustentar que uma economia desenvolvida possa se voltar para o subdesenvolvimento" (OSORIO, 2017, p. 157-158). Precisamente, Dados \& Connell (2018, p. 37) chamam a atenção sobre este aspecto particular: "Putting market society in world perspective raises serious doubts about the tendency to view the transformation of the global economy as one driven by changes in the global North". 
Tabela 2. Neoliberalismo \& Regimes estatais de Trabalho em Jessop: Schumpeteriano ou Ricardiano?

\begin{tabular}{|c|c|c|c|}
\hline $\begin{array}{l}\text { Variedades de } \\
\text { Capitalismo }\end{array}$ & Regime Fordista de Bem-estar & \multicolumn{2}{|c|}{$\begin{array}{c}\text { Regimes Pós-fordistas de Trabalho NEO-liberal } \\
\text { (Variedades e variegação) }\end{array}$} \\
\hline $\begin{array}{c}\text { Tipo de } \\
\text { Regime estatal }\end{array}$ & $\begin{array}{c}\text { Estado Nacional Keynesiano de } \\
\text { Bem-estar } \\
\text { (Keynesian Welfare National State, } \\
\text { KWNS) } \\
\text { Regime Prévio }\end{array}$ & $\begin{array}{c}\text { Estado Pós-Nacional Schumpeteriano de } \\
\text { Trabalho } \\
\text { (Schumpeterian Workfare Post-national State, } \\
\text { SWPS) } \\
\text { Regime de Transformação }\end{array}$ & $\begin{array}{c}\text { Estado Pós-Nacional Ricardiano de } \\
\text { Trabalho } \\
\text { (Ricardian Workfare Post-national State, } \\
\text { RWPS) } \\
\text { Regime de câmbio }\end{array}$ \\
\hline $\begin{array}{l}\text { Momento } \\
\text { econômico }\end{array}$ & $\begin{array}{l}\quad \text { Keynesiano } \\
\text { 1. Pleno Emprego. } \\
\text { 2. Economia Nacional } \\
\text { (relativamente) fechada. } \\
\text { 3. Gestão do "lado da demanda". } \\
\text { 4. Fornecimento nacional de infra- } \\
\text { estrutura. }\end{array}$ & $\begin{array}{l}\text { Schumpeteriano } \\
\text { 1. Inovação e flexibilidade. } \\
\text { 2. Economias (relativamente) abertas. } \\
\text { 3. Gestão do "lado da oferta" e competitividade. }\end{array}$ & $\begin{array}{l}\text { Ricardiano } \\
\text { Sob o lema da "urgência financeira": } \\
\text { 1. Redução do poder salarial do trabalho } \\
\text { (social e individual). } \\
\text { 2. Redução de "custos" para o Capital em } \\
\text { escala global (v.gr., matérias primas). }\end{array}$ \\
\hline $\begin{array}{l}\text { Momento social } \\
\text { (políticas) }\end{array}$ & \begin{tabular}{l}
\multicolumn{1}{c}{ Bem-estar } \\
1. Direitos econômicos e sociais \\
institucionalizados para todos os \\
cidadãos. \\
2. Formas de consumo coletivo que \\
dinamizam o fordismo.
\end{tabular} & $\begin{array}{l}\text { Trabalho } \\
\text { 1. Subordinação da política social às 'demandas' } \\
\text { da flexibilização do trabalho e da } \\
\text { empregabilidade. } \\
\text { 2. Imperativos sociais (salários) subordinados à } \\
\text { concorrência global (custos internacionais de } \\
\text { produção). } \\
\text { 3. Refuncionalização do Estado de bem-estar } \\
\text { aos interesses econômicos. } \\
\text { 4. Empreendedor e criação de sujeitos como } \\
\text { "parceiros" de economias flexíveis guiadas pelo } \\
\text { conhecimento para a inovação. }\end{array}$ & $\begin{array}{l}\text { Trabalho } \\
\text { 1. Austeridade institucional permanente. } \\
\text { 2. Políticas conjunturais de austeridade. } \\
\text { 3. Endurecimento dos ajustes pragmáticos } \\
\text { às políticas em favor do Capital. } \\
\text { 4. Rearticulação do poder social da moeda } \\
\text { e da propriedade (como Capital) e do } \\
\text { Poder político do Estado. } \\
\text { 5. Promover a "pré-carização" de todas as } \\
\text { áreas da vida através de mecanismos } \\
\text { disciplinares e fortalecimento da } \\
\text { financeirização da vida cotidiana. }\end{array}$ \\
\hline $\begin{array}{l}\text { Momento } \\
\text { territorial }\end{array}$ & \begin{tabular}{l}
\multicolumn{1}{c}{ Nacional } \\
Matriz estatal (territorial) \& \\
econômica
\end{tabular} & $\begin{array}{l}\text { Pós-Nacional } \\
\text { 1. Menor importância dos territórios nacionais } \\
\text { como “contentores de poder” (político, } \\
\text { econômico, cultural, etc.). } \\
\text { 2. Maior importância das Agências } \\
\text { internacionais e Fóruns intergovernamentais, os } \\
\text { quais moldam as agendas das políticas públicas. } \\
\text { 3. Emergência de Governos multinível } \\
\text { (governança) re-articulador do econômico e o } \\
\text { político. } \\
\text { 4. Devolução para os espaços subnacionais } \\
\text { (regionais, locais, urbanos) da coordenação na } \\
\text { formulação e implementação de políticas } \\
\text { públicas. }\end{array}$ & $\begin{array}{l}\text { Supra-TransNacional } \\
\text { 1. Desorganização das classes subalternas } \\
\text { e reorganização do bloco de poder } \\
\text { capitalista em torno de um viés pró- } \\
\text { exportador baseado na produção de } \\
\text { benefícios para o Capital, em geral e } \\
\text { fundamentalmente através de Tratados } \\
\text { internacionais. } \\
\text { 3. Integração não apenas em função das } \\
\text { estratégias de acumulação do Capital, mas } \\
\text { também a partir dos Projetos estatais e das } \\
\text { visões hegemônicas. }\end{array}$ \\
\hline $\begin{array}{l}\text { Momento } \\
\text { institucional } \\
\text { (organizacional) }\end{array}$ & \begin{tabular}{l}
\multicolumn{1}{c}{ Estatista } \\
Instituições estatais \\
complementares e/ou corretivas às \\
forças do mercado dentro de uma \\
"economia mista" em função do \\
crescimento econômico e a \\
integração social.
\end{tabular} & $\begin{array}{l}\text { (Meta) Governança } \\
\text { 1. Para compensar as "falhas" e "inadequações" } \\
\text { do mercado. } \\
\text { 2. Importância crescente das redes público- } \\
\text { privadas na atividade estatal em todos os níveis } \\
\text { (locais até supranacionais). } \\
\text { 3. Mudança do governo (tradicional) para a } \\
\text { governança (redes) em aspectos de política } \\
\text { econômica e social. } \\
\text { 4. Transição desde a intervenção tradicional } \\
\text { para regulações "brandas", lei reflexiva, } \\
\text { parcerias público-privadas, inteligência } \\
\text { organizacional. }\end{array}$ & $\begin{array}{l}\text { (Meta) Governança Pós-democrática } \\
\text { 1. Estado da Austeridade enraizado no } \\
\text { sistema político que institucionaliza o } \\
\text { processo político (politics), de políticas } \\
\text { (policies) e o governo estatal (polity) sob o } \\
\text { referente da austeridade. } \\
\text { 2. Subordinação do governo estatal aos } \\
\text { "imperativos" do mercado mundial e à } \\
\text { lógica do "valor de (inter)câmbio". } \\
\text { 3. Respostas institucionais crescentemente } \\
\text { autoritárias frente ao aumento de protestos } \\
\text { sociais em relação à "natureza" } \\
\text { tecnocrática e plutocrática da crise. }\end{array}$ \\
\hline
\end{tabular}

Fonte: elaborado pelo autor com base em Jessop (2018). 
Não é então uma casualidade senão uma causalidade que o neoliberalismo tenha como lugar de constituição in vivo et ab origine América Latina e o Caribe e que logo depois essaconfiguração se projete mundial e globalmente ${ }^{15}$.

Lembremos que o caminho da dependência econômico política dentro do assentamento de um tipo específico de Estado-nação capitalista na região latino-americana e caribenha como um todo durante as décadas de 1960 e 1970 responde com clareza meridiana ao duplo giro simultâneo para o autoritarismo no político, e o neoliberalismo no econômico ${ }^{16}$. A sucessão de golpes de Estado, a imposição de ditaduras cívico-militares por meio do terrorismo de Estado e, com isso, a presença de governos autoritários - tal e como acontece inicialmente nos países do Cone Sul, em última instância, no subcontinente todo, é a marca distintiva do EBA/RTM ${ }^{17}$.

Esta trajetória periférica não só figura como um episódio antecedente, mas assinalaria uma das marcas fundamentais dentro da emergência do $\mathrm{EST}^{18}$. Por isso, há que insistir na relação genética tanto histórica quanto estrutural e funcional entre o EBA/RTM e o EST.

15 O neoliberalismo, como projeto político e enquanto programa de políticas, irrompe cedo na América Latina e o Caribe através de formas autoritárias, paradigmaticamente manu militari mediante golpes de Estado e instalando regularmente ditaduras cívico-militares (patrocinadas pelos Estados Unidos). $\mathrm{O}$ ataque ao (primeiro) governo socialista democraticamente eleito de Salvador Allende figura como um momento marcante. O arco autoritário que se ativa desde meados de 1960 no Brasil e desencadeia-se desde o início da década de 1970 na Bolívia, Chile, Uruguai, Argentina, entre outros; não se deve relativizar o caso do Paraguai em 1954 nem formas anocráticas na Colômbia (PUELLOSOCARRÁS, 2017). A combinação vista na região entre i) autoritarismo político, ii) neoliberalismo econômico e iii) Doutrina de Segurança Nacional resulta uma regularidade. Cabe seguir insistindo que, pelo menos na sua expressão desde os programas econômicos, este "modelo" foi posteriormente transferido, ainda seletivamente, para a Inglaterra (Thatcher) e para os Estados Unidos (Carter e Reagan). Mais tarde, o plano econômico foi implantado globalmente via o (primeiro) Consenso de Washington de 1989, uma plataforma que, além do seu aparente lugar de enunciação, manteve uma marca tipicamente latino-americana (STOLOWICZ, 2016; PUELLO-SOCARRÁS, 2017).

16 Seja desde a noção de RTM do Marini (2013, p. 65): “A reorganização dos sistemas de produção latino-americanos, nos contextos da integração imperialista e ante o recrudescimento das lutas de classe na região, levou à implementação de regimes militares de corte essencialmente tecnocrático. A tarefa de tais regimes é duplo: por um lado, promover os ajustes estruturais necessários para pôr em marcha uma nova ordem econômica exigida pela integração imperialista; por outro, reprimir as aspirações de progresso material e os movimentos de reformulação política originados pela ação das massas”; ou, a partir da noção de EBA do O’Donnell (2008, p. 74): “(...) Institucionalmente, é um conjunto de organizações no que adquirem peso decisivo aquelas especializadas em coação assim como aquelas que tentam realizar a "normalização" da economia. Esse peso é a expressão institucional da definição, pelos seus próprios atores, das grandes tarefas que o BA tem que realizar: a reimplantação da "ordem" na sociedade por meio da eliminação da ativação política do setor popular, por uma parte, e a "normalização" da economia, pela outra"; as conclusões sobre o tipo de construção estatal são palpáveis.

17 Não deve se excluir que o pano de fundo do EBA/RTM reúne formas históricas concretas que vão desde os regimes políticos diretamente autoritários, tais como as ditaduras cívico-militares (típicas do Cone Sul do subcontinente nas suas diferentes gerações), bem como expressões anocráticas (regimes políticos variegados, ou seja: simultaneamente democracia e ditadura), onde o caso colombiano é paradigmático (ver Puello-Socarrás \& Puello-Socarrás, 2016).

18 De fato, a tendência política desde 1980 avança para o autoritarismo punitivo, inclusive, nos os chamados regimes liberais representativos. A taxa de encarceramento na Inglaterra e no País de Gales, por exemplo, declara Wacquant (2009, p. 433) aumentou de 88 prisioneiros por cada 100.000 habitantes em 1992 para 142 por cada 100.000 habitantes em 2004. No Brasil, enquanto no ano de 1996 a população carcerária registrava 148.000 pessoas privadas da liberdade, este mesmo número teria se triplicado em 2006, atingindo 400.000. 


\subsection{ESTADO PUNITIVO (PRISONFARE STATE)}

O duplo giro mencionado do EBA/RTM: o autoritarismo neoliberal, desborda sua singularidade espaço-temporal influindo na constituição efetiva do EST. O regime estatal tecnoburocrático-autoritário se espalha incidindo gradualmente através de diferentes mecanismos, embora agora em perspectiva global. O transe sistemático desde o periférico para o central, ou se se quiser: a generalização da especificidade capitalista (por exemplo, em termos da exploração redobrada, sobre-exploração do trabalho, da natureza, etc.), é um movimento crucial que na economia política contemporânea é frequentemente omitido ${ }^{19}$.

A transferência de tipos / estilos de programas de políticas públicas: (macro)econômicas e sociais $^{20}$ - inicialmente, o tristemente célebre Consenso de Washington, una formulação que resulta tipicamente latino-americana $^{21}$, por exemplo, serão determinantes chave para o arranjo Schumpeteriano centrado no Trabalho (Workfare State), o qual se desdobra além disso desde reformulações a nível governamental e organizacional.

Dois elementos complementares à caracterização (insistimos: incompleta) que oferece o EST devem ser sublinhadas em torno da natureza punitiva, policial e penal do Estado neoliberal.

Primeiro: a natureza de classe do neoliberalismo e sua articulação com as clivagens dos processos de opressão (gênero, etnia, inclusive etários, etc.). A evolução do neoliberalismo se

19 Marini (2013, p. 63) lembra precisamente que "Nos marcos da dialética do desenvolvimento capitalista mundial, o capitalismo latino-americano reproduziu as leis gerais que regem o sistema em seu conjunto, mas, em sua especificidade, acentuou-as até o limite... A lei geral da acumulação capitalista, que implica a concentração da riqueza num polo da sociedade e o pauperismo absoluto da grande maioria do povo, se expressa aqui com toda brutalidade..." [ênfase próprio].

$20 \mathrm{O}$ caminho de transferências parece responder a uma regularidade de trajetórias. As reformas previdenciárias neoliberais resultam ser, neste caso, ilustrativas: "The recent trend in pensions is characterized by finance's increasing role. This trend started with Chile's pension privatization in 1980, on the advice of Milton Firedman's "Chicago Boys". After the country's PAYG state scheme was completely replaced by compulsory funded schemes, the individual financial scheme spread around the rest of Latin America and into many post-Soviet countries" (SARITAS, 2017, p. 162).

$21 \mathrm{Um}$ antecedente inevitável dentro das discussões que trazem como resultado o primeiro Consenso de Washington é a obra: Rumo a uma renovação do crescimento econômico na América Latina, precisamente, editada pelo organizador da reunião de 1989: o Instituto de Economia Internacional (IIE, pela sua sigla em inglês), e de autoria de Bela Balassa (Consultor do Banco Mundial), Gerardo Bueno, Mario Henrique Simonsen (Fundação Getúlio Vargas, ex-ministro de Planejamento do Brasil) e Pedro-Pablo Kuczynski (ex-ministro de Energia e Minas e ex-presidente do Peru entre 2016-2018). A referência é fundamental porque, primeiro, como dizíamos sobre Stolowicz, o neoliberalismo in vivo emerge e desenvolve-se enquanto produção especial e especificamente latino-americana; segundo, após várias décadas, o EII (hoje: Instituto Peterson para a Economia Internacional) continua a desempenhar um papel fundamental - embora menos visível - desde os Estados Unidos dentro da rede de organizações chaves para a reconstrução neoliberal global no novo milênio. 
combina privilegiadamente com a exacerbação das dinâmicas, mas sobretudo das contradições do capitalismo histórico: exploração (econômica), dominação (política), opressão (social) e alienação (ideológica), embora agora levadas ao extremo limite. Isto, certamente, incide no tipo de transição do regime estatal:

(...) a substituição gradual de um (semi-)Estado de bem-estar por um Estado policial e penal para o qual a criminalização da marginalidade e o encarceramento punitivo das categorias desfavorecidas funcionam como uma política social no nível mais baixo da ordem étnica e de classe (...) o neoliberalismo produz não o recorte do governo, senão a instalação de um Estado centauro liberal para cima e paternalista para baixo que apresenta faces radicalmente diferentes nos dois extremos da hierarquia social: um rosto bonito e atento para as classes média e alta, e um rosto temível e sombrio para a classe baixa (WACQUANT, 2009, p. 80 e 437).

Segundo: o que está por trás deste regime punitivo influi poderosamente no novo tipo de (re)produção de ação institucional. Os antigos sistemas de Políticas públicas (é impossível esquecer que seu surgimento esteve social e historicamente subordinado ao EKB e aos "direitos sociais" da cidadania no capitalismo central), agora em retração, são transformados em um sentido fraco e, diríamos: com menor intensidade. Antes que políticas públicas o Estado neoliberal produzirá simples "medidas públicas" estatais que, certamente, existem à margem da problematização social: pobreza, desigualdade, etc., sempre extremas, uma tendência contemporânea já não potencial senão atualizada:

(...) O princípio reitor da ação pública neste campo não é a solidariedade senão a compaixão; seu propósito não é fortalecer os laços sociais senão reduzir as desigualdades, mas apenas para aliviar as mais gritantes dificuldades e para demonstrar a empatia moral da sociedade para com seus membros despossuídos, embora merecedores de sua ajuda (...) Além disso, o Estado penal hipertrofiado que pouco a pouco está substituindo ao Estado de bem-estar social no nível mais baixo da estrutura de classes - ou suplementando-o, de acordo com uma divisão do trabalho pelo gênero - é incompleto, incoerente e muitas vezes incompetente, de modo tal que não pode cumprir às expectativas pouco realistas que lhe fizeram nascer nem as funções sociais que lhe são próprias pela sua missão ( WACQUANT, 2009, p. 80).

Quando nos referimos, já não aos antecedentes originais do EST, especialmente em termos das transformações transnacionais, senão à sua consolidação gradual, concordamos no fundamental 
com a caracterização do Wacquant com respeito aos atributos centrais que se impõem na reconfiguração em vigor hoje, em torno do Estado Punitivo de Trabalho ${ }^{22}$ :

(...) o Estado centauro guiado por uma cabeça liberal montada em um corpo autoritário, aplica a doutrina do laissez-faire e laissez-passer quando se trata das desigualdades sociais e dos mecanismos que as geram (o livre jogo do capital, a escassa aplicação do direito trabalhista e a desregulação do trabalho, a retração ou eliminação das proteções coletivas), mas é brutalmente paternalista e punitivo quando se trata de lidar com suas consequências no dia a dia (...) a redução do setor de assistência social do Estado e o aumento concomitante de seu braço penal estão funcionalmente vinculados, configurando as dois caras da mesma moeda do Estado que se reestrutura nas áreas mais baixas do espaço urbano e social, na era do neoliberalismo cada vez mais acentuado. A retirada gradual da rede da segurança social começou no início dos anos setenta, como parte da oposição aos movimentos progressistas da década anterior, e culminou em 1996 com a conversão do direito "assistência" (Welfare) na obrigação de "trabalhar em troca de assistência" (Workfare) destinada a dramatizar e valorizar a ética do trabalho no nível mais baixo da escala laboral. (WACQUANT, 2009, p. 82)

A anterior aproximação, porém, ainda estaria em dívida e sem observar outros elementoschaves sem os quais é impossível articular eventos de mais recente emergência. $O$ princípio antropolítico e praxiológico do Empreendedor e o referencial do empreendedorismo são cruciais para que seja mais bem compreendido o tipo de Estado contemporâneo fruto do Novo Neoliberalismo.

\subsection{ESTADO EMPREENDEDOR (ENTREPREUNERIAL STATE)}

Nas transformações políticas e socioeconômicas do Estado neoliberal contemporâneo, onde o empreendedor não é apenas o princípio antropológico por excelência, mas também o princípio político, deveriam se desenvolver, pelo menos, três premissas básicas complementares que suportem a (chamada) Acumulação empreendedora do capitalismo tardio ${ }^{23}$.

22 Esta interpretação não implica: 1) considerar que o regime estatal anterior (EKB) - ou qualquer outro, no marco do sistema capitalista - funcione fora dos processos da exploração econômica, a dominação política, a opressão social ou a alienação ideológica. Desde logo, não se coloca entre parênteses as diferentes formas de violência estatal empregadas a partir da pretensão irrenunciável do Estado capitalista de exercer seu monopólio físico e simbólico. O contraste, em todo caso fictício, entre o autoritarismo estatal latino-americano e a democratização euro-americana, particularmente exaltado nas décadas dos anos sessenta e setenta, pouco a pouco se tem diluído, revelando a natureza eminentemente autoritária do neoliberalismo (PUELLO-SOCARRÁS, 2008). 2) Como o temos explicado antes, está errado (e induze ao erro) Wacquant ao relacionar a doutrina do laissez-faire / laissez-passer com o neoliberalismo.

23 A figura do empresário remonta a autores do século, como A. de Montchrestien e, especialmente, R. Cantillon. Contemporaneamente, a teoria do empresário deve estar relacionada com o trabalho de J. Schumpeter. No entanto, o referente empresarial, num sentido propriamente neoliberal, deve apontar para L. Mises, I. Kirzner e G. Schmölders para derivar, pelo menos, três dimensões básicas: i) como ator social-individual; ii) contextos sociais e institucionais; 
Em primeiro lugar, as lógicas e contradições do novo taylorismo (CASILLI, 2018), ou fordismo individualizado (DEMICHELIS, 2016), âmbito plausível que permitiria registrar, além das rupturas pós-fordistas, as fortes continuidades nos processos do capitalismo em sua fase neoliberal, especialmente, ao nível do individualismo extremo e as implicações que daí derivam dentro das dinâmicas de exploração econômica e, particularmente, da alienação ideológica.

A instalação do indivíduo enquanto empreendedor, "empresário de si mesmo", como protagonista social é uma via privilegiada para a destruição (destituição e desinstitucionalização) dos processos de socialização coletiva não capitalista. Especialmente aqueles de natureza comunal que, embora estejam hoje integrados e subordinados à lógica do Capital, ainda permanecem à margem de vários mecanismos de mercantilização total e, pelo momento, não têm sido completamente "funcionais" à acumulação capitalista. Ou, em outras palavras, formas sociais que politicamente existem como resistências de diferente ordem e organização, atual e potencial.

Não resulta menor então validar se, em meio da transição para o Estado neoliberal, como o lembra Demichelis (2016):

Realmente temos saído felizmente (e finalmente!) do fordismo sufocante e pesado do século XX para chegar ao pós-fordismo leve, flexível e virtuoso, à produção ágil, à economia do conhecimento e à era do acesso, à "new economy" dos anos 90 , e agora à "sharing economy" [Nota: "economia colaborativa"] e aos "smart jobs" [Nota: "empregos inteligentes"], e há quem (Paul Mason) até imagina um fabuloso pós-capitalismo? Ou estamos simplesmente (e dramaticamente) em uma nova fase do Grande Relato técnico e capitalista? (DEMICHELIS, 2016)

E, em consonância com o "novo Taylorismo" proposto por Casilli (2018):

A mutação que - erroneamente - temos chamado pós-fordismo e agora "sharing economy" e fábrica 4.0 tem tido lugar, então, não nas formas e nas regras de organização (subdivisão e totalização: do trabalho de produção, do trabalho de consumo, na fruição dos produtos da indústria cultural), senão na qualidade e na quantidade desta individualização. Se ontem no fordismo era necessário concentrar milhares de trabalhadores dentro de locais fechados como eram precisamente as grandes fábricas, porque o meio de conexão/totalização das partes subdivididas do trabalho eram necessariamente físico e pressupunham um espaço concentrado e concentrador (isto permitia a eficiência produtiva daquela época), hoje o meio de conexão, ou seja, a Rede, permite quebrar e individualizar $\mathrm{n}$ vezes mais a forma e a regra de organização e fazê-la explodir em empregos (e em trabalhadores) desconectados [sic] de um lugar físico (a fábrica), mas conectados em um lugar virtual, como é precisamente a Rede. Do fordismo concentrado de ontem temos passado, assim pois, não ao pós-fordismo senão a um fordismo individualizado... (CASILLI, 2018)

iii) sistemas de inovação: níveis e funções de gestão (PLEHWE, 2020). 
Em segundo lugar, o processo de reconversão e (contra)reformas estatais, nos níveis governamental (direção e dominação política) e organizacional (aparelhos).

A passagem desde a governabilidade do EKB e o EBA/RTM - agora uma pretensão anacrônica e improdutiva para apoiar a hegemonia desde o consenso e legitimidade das "massas" - para diferentes modalidades de governance e os eixos da "co-ordenação" e "co-operação" público-privadas; uma forma de fechar o caminho das alternativas comunais baseadas na cooperation e partnership sob um substrato ontologicamente distinto das primeiras ${ }^{24}$.

Complementarmente, o transe desde as burocracias estatais para estruturas funcionalmente pós-burocráticas ${ }^{25}$ : desde cedo sob a premissa da "desregulação" estatal (os modelos de contrarreforma baseados na "Reinvenção do governo"); depois, em torno do paradigma pósburocrático do Estado modesto, ou seja, regulador (como em M. Crozier), o qual encontra seu zênite na Nova Gestão Pública e o domínio público-e-privado. Este trajeto, que aparentemente permite novas disjuntivas, como a Pós-nova Gestão Pública ou o Valor Público, são reflexo, por um lado, do esgotamento funcional do New public management como fórmula organizacional na produção de medidas públicas; e, por outro, (pretendida) renovação do neoliberalismo organizacional com alguma solução de continuidade (ABDALA; PUELLO-SOCARRÁS, 2019).

O empreendedor público se localiza, assim, como o "gestor" da dinâmica política no marco de uma "Pós-Nova" Gestão do Valor Público orientada a Missões e não mais "por resultados" como na NGP do passado (MAZZUCATO; PENNA, 2016; MAZZUCATO, 2021).

24 Vincent Ostrom, por exemplo, em The intellectual crisis of American public administration (publicado em 1973) legitima o empreendimento para o setor público, com os empreendedores públicos à cabeça, ao assegurar que a administração pública (americana) estaria - na sua opinião - mais envolvida com o empreendimento que com o management (citado pelo STEDMAN, 2018). As dinâmicas do governo poderiam ser assim homologadas com o funcionamento dos mercados "imperfeitos", os quase-mercados. A continuação desta ideia, por parte de sua esposa: Elinor Ostrom - a primeira mulher, além disso: não economista, a ganhar o prêmio Nobel de Economia - (PUELLOSOCARRÁS, 2012) em torno à Governança policêntrica sintetiza a pretensão do novo neoliberalismo de construir espaços públicos-e-privados, além da dicotomia Estado-o-Mercado, elevando ao empreendimento e o empreendedor público como elementos-chave.

25 Há que assinalar que a crítica ao "burocratismo" de meados de 1960, a qual seria decisiva durante as décadas seguintes para o surgimento da orientação pós-burocrática, longe de se esgotar nas burocracias estatais, sinalizaria stricto sensu ao critério organizacional social, ou seja, a sociedade como totalidade. Os apontamentos deste tipo à Grande empresa capitalista procuravam "reivindicar" assim o "pequeno mundo empresarial" o qual, tal e como o sublinham Bolstanski e Chiapello (2002, p. 108) com relação à introdução a nível empresarial da direção por objetivos: "Nenhum dirigente trabalha provavelmente com tanto empenho e de forma tão eficaz quanto aquele que dirige seu próprio negócio... O problema para a grande empresa consiste, portanto, em criar as condições de trabalho nas quais o quadro seja, na medida do possível, seu próprio patrão" [ênfase próprio]. Assim sendo, mesmo que sintetizemos o movimento ao nível do Estado enquanto aparelho deve também se interpretar o fenômeno enquanto relação social reconfigurada pela fase neoliberal. 
Por fim, em terceiro lugar, com o "Estado empreendedor", o (novo) neoliberalismo se projeta, incorporando a necessidade de fortalecer a faceta regulatória que vem consolidando como consenso político e orientação nas políticas, pelo menos, durante o século XXI (PUELLOSOCARRÁS, 2017).

Trata-se agora de impulsionar um tipo de ação estatal renovada tanto mais complexa quanto proativa, desde logo, sempre em função dos mercados. Em convergência com o pensamento do M. Friedman quem lembrava na série de televisão da década de 1980, intitulada: Liberdade de escolha, mais tarde publicada sob o subtítulo: "Para um novo liberalismo econômico" (FRIEDMAN; FRIEDMAN, 1998) que o Estado é o instrumento crucial que recria as condições para o funcionamento dos mercados, Mazzucato (2014, p. 9) restabelece a ideia de um "ecossistema de inovação público-privado simbiótico (mais mutualista)" não somente para "corrigir" as falhas dos mercado e/ou “complementá-los" senão fundamentalmente porque ${ }^{26}$ :

(...) o Estado deve liderar... não simplesmente corrigir as falhas de mercado, senão ativamente criar e moldar (novos) mercados enquanto regula os já existentes (...) Desde a Internet até a tecnologia do fracking (MAZZUCATO, 2014, p. 6; 8).

(...) há que começar por admitir que o Estado faz bastante mais que remediar as falhas do mercado, que é a forma como os economistas normalmente justificam as despesas públicas. A verdade é que o Estado tem formado e criado mercados assumindo grandes riscos. (MAZZUCATO, 2013)

O eixo do empreendimento sofre então um deslocamento crucial: desde o indivíduo (singularmente localizado) para a dimensão relacional, ou seja, a relação social capitalista básica: capital-trabalho e na qual o Estado (e seus aparelhos) está(ão) coletiva e socialmente considerado(s) e disposto(s) para apoiar a relação empreendedora que implica o neoliberalismo tardio. Não só em termos da exploração (econômica), senão também - como dissemos antes - a partir da dominação (política) e da opressão (social), processos que se aprofundam dinamizando-se desde a alienação ideológica empreendedora.

26 Naturalmente, a nova ênfase re-regulatória do Estado neoliberal no século XXI não significa abandonar suas expressões desregulatórias (típicas do século XX), embora as subordine sim, evitando o intervencionismo estatal e tornando impossível qualquer oportunidade para o "desvio" que supõe o planejamento centralizado já seja como decisão organizativa ou como orientação política provável. Há que notar que não por acaso os chamados ao Estado empreendedor pretendem que o Estado, enquanto objetivação coletiva e social, seja quem assumisse em adiante os riscos e também os investimentos da acumulação de capital. Precisamente, duas das variáveis cruciais, mas também críticas, dentro da crise atual do sistema ("de rentabilidade" e "de investimento") (ROBERTS, 2016). 
Não é então por acaso que, nesta versão emergente de regime estatal, seja elevada uma (aparente) crítica ao empreendedor "individual” - e, sem substituí-lo - promova-se a ideia de um “empreendedor coletivo", o Estado:

(...) Toda a tecnologia que faz do iPhone um telefone inteligente está em dívida com a visão e o apoio do Estado: a internet, o GPS, a tela sensível ao toque e até mesmo a voz assistente Siri do Smartphone receberam dinheiro do Estado. (...) A "economia real" (de bens e serviços) tem experimentado uma mudança semelhante à da "economia financeira": cada vez mais o risco se move para o setor público e o setor privado recebe os benefícios...

Esqueçam-se dos "empreendedores" e os "inovadores" do Silicon Valley. O Estado é quem deveria receber o reconhecimento por financiar a tecnologia criadora de riqueza. (MAZZUCATO, 2013)

O Estado empreendedor reorganiza seus aparato e ações (geralmente, tímidas medidas políticas, as quais estariam longe de se constituir em Políticas públicas, no sentido clássico do termo, insistimos) em torno das dinâmicas empreendedoras - ocultando suas contradições - para entrar a apoiar e atualizar a relação capitalista.

Esta estrutura sociopolítica para se manter vigente lhe resulta imprescindível, por um lado, gerir taticamente (no curto prazo) o cenário da insegurança social intensiva e estendida, acentuada pelo próprio neoliberalismo ${ }^{27}$; e, pelo outro, continuar norteando - avançando - na edificação estratégica (no longo prazo) de Sociedades de Mercado. Aqui, o empreendorismo estatal cumpre a função econômica de aprofundar a exploração em geral, condição que só pode ser assegurada, ao mesmo tempo, pela função ideológica da alienação (redobrada).

Neste sentido o novo Estado neoliberal deve ser observado compreensivamente em sua tripla condição de Estado Punitivo de Trabalho Empreendedor (prison + workfare + entrepreunerial) (ver figura 2).

\section{CONSIDERAÇÕES FINAIS}

A designação Novo Neoliberalismo permite não apenas enfatizar os atributos cruciais deste processo econômico político no novo milênio. Ele também consegue capturar as novidades e os

27 O correlato do Estado empreendedor -o qual é ocultado sistematicamente por seus promotores intelectuais sob o eufemismo da "inovação" - é realizada principalmente de duas maneiras: i) o consenso da força: crescente repressão e criminalização estatal; ii) a força do consenso: "bem-estar" relativo e focalizado nas margens extremas das desigualdades, exclusões, opressões, etc. 
atributos-chave, relativamente inéditos, da nova fase do capitalismo neoliberal no e para o século XXI. Por sua vez, uma mediação complexa e, portanto, a combinação múltipla do (novo) Estado neoliberal a partir do caráter Punitivo, Empreendedor e de Trabalho (EPET) sintetiza - no fundamental - as reconfigurações do neoliberalismo tardio. Registra de forma complementar os modos de estruturação dos aparelhos estatais em torno da gestão pós-burocrática e da governança (multinível e policêntrica; também caracterizada como pós-democrática e autoritária), enquanto a modalidade típica do governo neoliberal contemporâneo.

Figura 2. Trajetória histórica de transição do EKB e EBA ao EST para o EGA.

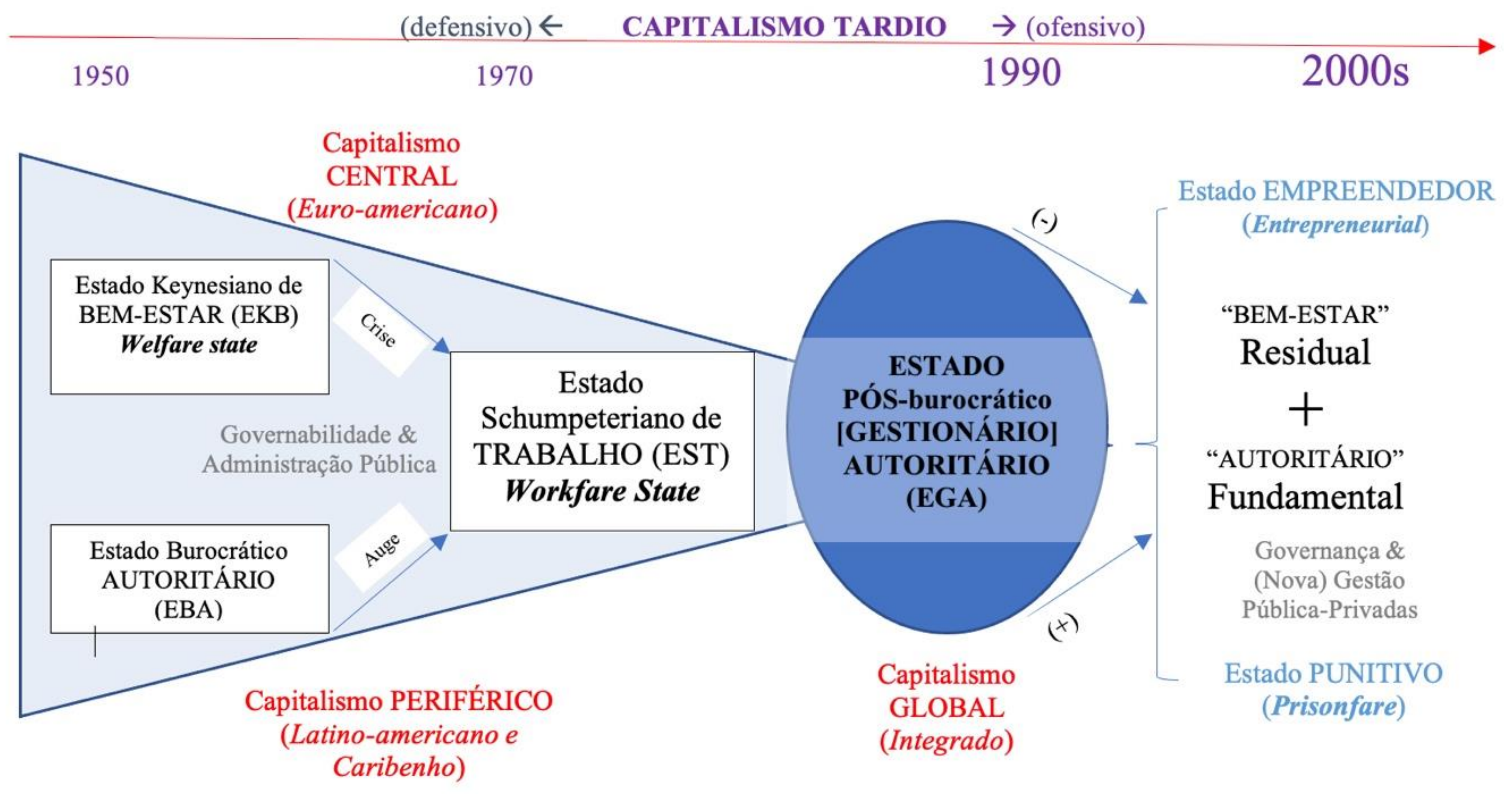

Fonte: elaboração própria.

A crise e resiliência do neoliberalismo como Projeto político transnacional da classe capitalista na virada ao século XXI sugere que a transição para uma versão complexa e emergente (heterodoxa), aprofunda, garante e potencializa a continuidade histórica de suas trajetórias para o novo milênio. 


\section{REFERÊNCIAS}

ABDALA, P.; PUELLO-SOCARRÁS, J.F. Reflexiones sobre la Administración pública y el neoliberalismo en Nuestramérica, Siglo XXI. ReAD. Revista Eletrônica de Administração, vol. 25, No. 2, 2019.

ACOSTA, A.; CAJAS, J. Correa, un neo-neoliberal. Rebelión, 7 feb. 2017. Disponível em: https://pueblosencamino.org/?p=3585.

BARZELAY, M.; ARMAJANI, B. Atravesando la burocracia: una nueva perspectiva de la administración pública. México: FCE, 1998.

BETTLEHEIM, C. Planeación y crecimiento acelerado. México: FCE, 1965.

BIRDSALL, N., DE LA TORRE, A. y VALENCIA, F. The Washington Consensus. Assessing damage Brand, Policy Research Working Paper (WPS5316), Washington: World Bank, 2010.

BLYTH, M. Austeridad. Historia de una idea peligrosa. Barcelona: Planeta, 2014.

BRESSER-PEREIRA, L.C. An account of new developmentalism and its structuralist macroeconomics. Brazilian Journal of Political Economy, p. 493-502, v. 31, n. 3, 2011.

BOLTANSKI L; CHIAPELLO, E. El nuevo espíritu del capitalismo. Akal: Madrid, 2002.

BONAL, X. The neoliberal educational agenda and the legitimation of crisis: old and new state strategies. British Journal of Sociology of Education, v. 24, n. 2, 2003.

BOZEMAN, B. Public values and public interest: counterbalancing economic individualism. Washington: Georgetown University Press, 2007.

BROWN, W. In the ruins of neoliberalism: the rise of antidemocratic politics in the West. Columbia University Press, 2019.

CAFFENTZIS, G. Una crítica del Capitalismo cognitivo. Hipertextos, v. 4, n. 6, 2016. Disponível em: https://revistas.unlp.edu.ar/hipertextos/article/view/7655. Acesso em: 12 nov. 2020.

CASILLI, A. Los trabajadores son el corazón del algoritmo: El nuevo capitalismo digital. Entrevista, Sinpermiso, 2018. Disponível em: <http://www.sinpermiso.info/textos/lostrabajadores-son-el-corazon-del-algoritmo-el-nuevo-capitalismo-digital-entrevista $>$. Acesso em 12 nov. 2020.

CENTRO DE ESTUDIOS PÚBLICOS. Bases de la Política económica del Gobierno militar chileno. Santiago: Alfabeta, 1973[1992]. 
CHRISTENSEN, T.; LæGREID, P. Reformas Post nueva gestión Pública. Tendencias empíricas y retos académicos. Gestión y Política Pública, v. XVI, n. 2, 2007, p. 539-564.

COASE, R. La empresa, el mercado y la ley. Madrid: Alianza, 1994.

CROZIER, M. Estado modesto, Estado moderno: estrategia para el cambio. México: Fondo de Cultura Económica, 1992.

CROZIER, M., HUNTINGTON, S.; WATANUKI, J. The Crisis of Democracy: Report on the Governability of Democracies to the Trilateral Commission. New York: New York University Press, 1975.

DADOS, N.; CONNELL, R. Neoliberalism in World perspective: Southern origins and southern dynamics. In: CAHILL, D., COOPER, M., KONINGS, M.; PRIMROSE, D. (eds.). The SAGE Handbook of Neoliberalism. Los Angeles: SAGE Reference, 2018, p. 28-39.

DAHL, A.; SOSS, J. Neoliberalism for the Common Good? Public value Governance and the downsizing of democracy. Public Administration Review, v. 74, n. 4, 2014, p. 496-504.

DARDOT, P.; LAVAL, C. La nueva razón del mundo: Ensayo sobre la Sociedad neoliberal. Madri: Gedisa, 2013.

. Foucault, Neoliberalism and Europe. In: CAHILL, D., COOPER, M., KONINGS, M.; PRIMROSE, D. (eds.). The SAGE Handbook of Neoliberalism. Los Angeles: SAGE Reference, 2018, p. 193-200.

. Anatomía del nuevo neoliberalismo. Viento del Sur, n. 164, jul., 2019. Disponível em: <https://vientosur.info/spip.php?article14984>. Acesso em 12 jul. 2019.

DAVIES, W. El Nuevo Neoliberalismo. New Left Review, n. 101, nov. -dic., 2016.

DEMICHELIS, L. El nuevo fordismo individualizado. SinPermiso, 2016. Disponível em: <http://www.sinpermiso.info/textos/el-nuevo-fordismo-individualizado>. Acesso em 12 nov. 2020.

DUNLEAVY, P., MARGETTS, H., BASTOW, S.; TINKLER, J. New public management is dead - Long live digital-era governance. Journal of Public Administration Research and Theory, $\mathrm{n}$. 16, 2006, p. 467-494.

EAGLETON-PIERCE, M. Neoliberalism: The key concepts. New York: Routledge, 2016.

FRIEDMAN, M.; FRIEDMAN, R. Libertad de elegir: Hacia un nuevo liberalismo económico. Buenos Aires: Grijalbo, 1998.

GARCÍA LINERA, A. Ser de izquierda en el Siglo XXI. Ciclo de Conferências. Montevidéu, 12 mai., 2017.Disponível em: 〈 http://bit.ly/2qmwF4F>. Acesso em 12 nov. 2020. 
GUERRERO, O. La nueva gerencia pública: Neoliberalismo en Administración pública. México: Fontamara, 2004.

HAYEK, F. Camino de servidumbre: Textos y documentos. Ed. definitiva. Madrid: Unión Editorial, 2008[1994].

HAYEK, F. Individualismo: El verdadero y el falso. Estudios Públicos, n. 22, 1986[1975].

HAYEK, F. Opening address to a conference at Mont Pèlerin. In: HAYEK, F. The Collected works of F.A. Hayek. v. IV. Chicago: University of Chicago Press, 1992[1947], p. 237-248.

HOWKINS, J. The Creative Economy: How people make money from ideas. London: Allen Lane, 2001.

JESSOP, B. ¿Hacia un Estado Schumpeteriano de Trabajo? Observaciones preliminares sobre la economía política post-fordista. In: JESSPO, B; BULA, J. Crisis del Estado de Bienestar: Hacia una nueva teoría del Estado y sus consecuencias sociales. Bogotá: Siglo del Hombre, 1999, p.

- ¿Narrando el futuro de la economía nacional y el Estado nacional? Puntos a considerar acerca del replanteo de la regulación y la re-invención de la gobernancia. Documentos y Aportes en Administración Pública y Gestión Estatal, a. 6, n. 7, p. 7-44, 2008.

Neoliberalism and Workfare: Schumpeterian or Ricardian? In: CAHILL, D., COOPER, M., KONINGS, M.; PRIMROSE, D. (eds.). The SAGE Handbook of Neoliberalism. Los Angeles: SAGE Reference, 2018, p. 347-358.

LANE, J. New Public Management. London: Routledge, 2000.

MARINI, R. M. Subdesenvolvimento e revolução. Florianópolis: Insular, 2013.

MARX, C. El Capital: Crítica de la Economía Política. Madrid: Akal, 1976.

MAZZUCATO, M.; PENNA, C. The Brazilian Innovation System. A misión-oriented policy proposal. Avaliação de Programas em CT\&I. Apoio ao Programa Nacional de Ciência (Plataformas de conhecimento). Brasília, DF: Centro de Gestão e Estudos Estratégicos, 2015.

MAZZUCATO, M. Mission Economy: A Moonshot Guide to Changing Capitalism.

London: Penguin Random House, 2021.

MAZZUCATO, M. El Estado emprendedor: Mitos del sector público frente al sector privado. Barcelona: RBA, 2014.

El mito puramente ideológico de los "emprendedores" privados tecnológicamente innovadores. SinPermiso, 6 out. 2013. Disponível em: <http://www.sinpermiso.info/textos/el- 
mito-puramente-ideolgico-de-los-emprendedores-privados-tecnolgicamente-innovadores>.

Acesso em 6 out. 2013.

MIROWSKI, P. Nunca dejes que una crisis te gane la partida: ¿Cómo ha conseguido el neoliberalismo, responsable de la crisis, salir indemne de la misma? Barcelona: Planet, 2013.

MISES, L. Kritik des Interventionismus: Untersuchengen zur Wirtscaftspolitik und Wirtschaftsideologie der Gegenwart. Jena: Gustav Fischer, 1929.

MOORE, M. Creating Public Value: Strategic Management in Government. Harvard University Press, 1997.

MÜLLER-ARMACK, A. Economía Social de Mercado. In: Una mirada a la teoría, a los modelos económicos, a las bases conceptuales y al modelo de la "Economía Social de Mercado". La Paz: Konrad Adenauer Stiftung, 2011 [1956].

NICOLI, M.; PALTRINIERI, L. El tránsito del empresario de sí mismo a la start-up existencial en el marco de las transformaciones de la racionalidad neoliberal. RECERCA. Revista de Pensament I Anàlisi, v. 24, n. 1, 2019.

O'DONNELl, G. El Estado Burocrático-Autoritario. Triunfos, derrotas y crisis. Buenos Aires: Editorial Belgrano, 1982.

OSBOURNE, D.; GAEBLER, T. La reinvención del gobierno: La influencia del espíritu empresarial en el sector público. Barcelona: Paidós, 1992.

OSBOURNE, D.; PLASTRICK, P. Herramientas para transformar el gobierno. Barcelona: Paidós, 2006.

PECK, J., BRENNER, N.; THEODORE, N. Actually existing neoliberalism. In: CAHILL, D., COOPER, M., KONINGS, M.; PRIMROSE, D. (eds.). The SAGE Handbook of Neoliberalism. Los Angeles: SAGE Reference, 2018, p. 321-328.

PLEHWE, D. The origins of the neoliberal economic development discourse. In: MIROWSKI, P; PLEHWE, D. (eds.). The Road from Mont-Pèlerin: The making of the neoliberal thought collective. Cambridge: Harvard University Press, 2009, p. 238-279.

. Coaliciones discursivas transnacionales y política monetaria: Argentina y los poderes limitados del Consenso de Washington, Anuario de Estudios Políticos Latinoamericanos, n. 2. Bogotá: Universidad Nacional de Colombia, Maestría en Estudios Políticos Latinoamericanos, 2015, p. 125-166.

PLEHWE, D. Schumpeter revival? How neoliberals revised the image of entrepreneur. In: MIROWSKI, P; PLEHWE, D.; SLOBODIAN, Q. Nine Lives of Neoliberalism. Londres: Verso, 2020, p 120-142. 
PUELLO-SOCARRÁS, J.F. Nueva Gramática del Neo-liberalismo: Itinerarios teóricos, trayectorias intelectuales, claves ideológicas. Bogotá: Universidad Nacional de Colombia, Facultad de Derecho, Ciencias Políticas y Sociales, 2008.

. Ocho tesis sobre el neoliberalismo (1973-2013). In: RAMÍREZ, H. O neoliberalismo Sul-americano em clave transnacional: enraizamento, apogeu e crise. São Leopoldo: Oikos - Unisinos, 2013, p. 13-57.

- Paleontología (política) de una idea (neoliberal), Estudios Críticos del Desarrollo, v. V, n. 8, primeiro semestre, 2015, p. 47-81.

. Las críticas neoliberales al neoliberalismo: El Dogma de mercado y las Herejías que nunca llegan a convertirse en Blasfemias, Anuario de Estudios Políticos Latinoamericanos, n. 3, Bogotá: Universidad Nacional de Colombia, 2017, p. 179-204.

- ¿Gobernanza y Nueva Gestión Pública para la Paz? Notas sobre el proceso de implementación del Acuerdo Final en Colombia. REAd. Rev. eletrôn. adm., v. .24, n. 2, 2018a p.31-49, 2018. Disponível em: < http://www.scielo.br/scielo.php?script=sci_arttext\&pid=S141323112018000200031>. Acesso em 12 nov. 2020.

- ¿Heteronomía relativa? Esbozos en torno a la inversión de la "lógica" en las políticas públicas en la era del Capitalismo neoliberal, 2018b, no prelo.

. Desde la Gobernanza (neoliberal) hacia las Habilidades Comunales de Gobierno. Formas comunales de gobierno desde abajo como alternativas contra-hegemónicas, Anuario de Estudios Políticos Latinoamericanos, n. 4. Bogotá: Universidad Nacional de Colombia, 2018c, p. $65-84$.

. La Economía Naranja: Otra "innovación” neoliberal para exprimirle el jugo a los trabajadores. Revista Izquierda, n. 73, 2018d, p. 47-53.

. Nuevo Neo-liberalismo y Administración Pública. Reinvención gubernamental, post-burocracia y nueva gestión pública. In: RODRÍGUEZ, Y.; PUELLO-SOCARRÁS, J. F. Vademecúm de la Administración Pública: Debates y Perspectivas, n. 1. San Juan de Pasto: APESAP, 2018e.

La llamada Acumulación Emprendedora: El Estado emprendedor del Nuevo Neoliberalismo, siglo XXI. Cali: Universidad del Valle, 2019 (no prelo).

PUELLO-SOCARRÁS, G.E.; PUELLO-SOCARRÁS, J.F. (2017) ¿La época de los 'post'? Conflicto social-armado, acuerdo de paz y anocracia neoliberal en Colombia. In: VIDAL De La Rosa, G. Política Latinoamericana Contemporánea. México: Universidad Autónoma Metropolitana, 2019, p. 305-346.

REINHOUDT, J.; AUDIER, S. The Walter Lippmann Colloquium: The birth of neoliberalism. 
Basingstoke: Palgrave MacMillan, 2018.

ROBERTS, M. The Long Depression: How it happened, why it happened and what happens next. Chicago: Haymarkets books, 2016.

ROUQUIÉ, A. A la sombra de las dictaduras: La democracia en América Latina. Buenos Aires: FCE, 2011.

RÜSTOW, A. Freire Wirtschaft - Starker Staat (Die staatspolitischen Voraussetzungen des wirtschaftspolitischen Liberalismus). In: BOESE, F. (ed). Deutschland und die Weltkrise, Schriften des Vereins für Socialpolitik. Dresden: Duncker \& Humbolt, 1932, p. 62-69.

SARITAS, S. Pensions and Social reproduction. In: BHATTACHARYA, T. (ed.). Social Reproduction Theory: Remapping Class, Recentering Oppression. London: Pluto Press, 2017.

SCHRAM, S. Neoliberalizing the Welfare state. Marketizing social policy / Disciplining clients, In: CAHILL, D., COOPER, M., KONINGS, M.; PRIMROSE, D. (eds.). The SAGE Handbook of Neoliberalism. Los Angeles: SAGE Reference, 2018, p. 308-322.

SOLÍS, JL. El Estado como categoría de la crítica marxista de la economía política: el debate sobre la "derivación". In: ARTOUS, A., HAI HAC, T., SOLÍS, J.; SALAMA P. Naturaleza y forma del Estado capitalista. Buenos Aires: Herramienta, 2016, p. 99-129.

STANDING, G. El precariado bajo el capitalismo rentista. SinPermiso, 15 abr., 2018. Disponível em: https://www.sinpermiso.info/textos/el-precariado-bajo-el-capitalismo-rentista. Acesso em 15 abr. 2018.

STEDMAN, D. The neoliberal origins of the Third Way: How Chicago, Virginia and Bloomington shaped Clinton and Blair. In: CAHILL, D., COOPER, M., KONINGS, M.; PRIMROSE, D. (eds.). The SAGE Handbook of Neoliberalism. Los Angeles: SAGE Reference, 2018, p. 167-178.

STIGLITZ, J. Más instrumentos y metas más amplias para el desarrollo: Hacia el Consenso PostWashington. Desarrollo Económico, v. 38, n. 151, 1998.

. "La crisis de Wall Street es para el mercado lo que la caída del muro de Berlín fue para el comunismo" (entrevista). El País, 21 set. 2008. Disponível em: <https://elpais.com/diario/2008/09/21/negocio/1222002874_850215.html>. Acesso em 12 nov. 2020.

STOLOWICZ, B. El misterio del posneoliberalismo: la estrategia para América Latina. Bogotá: Espacio Crítico, 2016, p. 85-126.

TINBERGEN, J. Central Planning. New Haven e Londres: Yale University Press, 1964.

WACQUANT, L. Castigar a los pobres: El gobierno neoliberal de la inseguridad social. Barcelona: Gedisa, 2009. 
WHITESIDE, H. Neoliberalism as Austery. The theory, practice, and purpose of fiscal restraint since 1970s. In: SPRINGER, S., BIRCH, K.; MACLEAVY, J. The Handbook of Neoliberalism. New York. Routledge, 2016, p. 132-141.

WATKINS, S. Arenas movedizas. New Left Review, n. 61, p. 5-27, 2010.

WILLIAMSON, J. Appendix: Our agenda and the Washington Consensus. In: KUCZYNSKI, P.P.; WILLIAMSON, J. After the Washington Consensus: restarting growth and reform in Latin America. Washington: Institute for International Economics, 2003.

. What the Washington Consensus means by policy reforms. In: WILLIAMSON, J. (ed.). Latin American adjustment: how much has happened. Washington: Institute for International Economics, 1990.

ZAVALETA MERCADO, R. Clase y Conocimiento, La autodeterminación de las masas. Bogotá: Siglo del Hombre / CLACSO, 2009[1975], p. 67-75. 